\title{
NEVINOST DJECE I TAJNI ŽIVOTI ODRASLIH U PROZI FLANNERY O'CONNOR **
}

U O'Connorinom romanu Mudra krv, kao i u pripovijetki „Hram Svetog Duha“, dijete-protagonista susreće se sa nekom tajnom života odraslih. Gotska fikcija, kako dokazujemo, uvijek podrazumijeva perspektivu nevinosti koja omogućava da priča ostane trajno nerazumljiva, fragmentirana, a time i zastrašujuća. Gotska narativna perspektiva se uspostavlja tek tamo gdje postoji neka netransparentnost, neki „mrtvi ugao“, zagonetka u pogledu prirode svijeta i ljudi, nešto neodgonetljivo i mračno. Djetinjstvo je (u „Hramu Svetog Duha“ u kojem anonimna djevojčica prisluškuje nejasan govor o „dvopolnoj nakazi“ ili u Mudroj krvi u kojoj dječak Hazel Motes posmatra „zabranjeni prizor“ u cirkusu) postalo mjesto nevine perspektive iz koje se može vidjeti nešto od tajni odraslih, neka još uvijek mračna i nejasna istina o stvarnom životu i svijetu, govor ili prizor posredovan kodovima opreznosti, odlomcima prijetećih riječi. U ovoj vrsti proze, dječji pogled „goticizuje“ tajne odraslih. No, kod O'Connorove dešava se važan značenjski obrt: gotska „praznina“ ostavljena nepotpunim razmijevanjem popunjava se, neočekivano, modelima biblijske sakralnosti. Ove promjene epistemičke perspektive (iz gotske „epistemičke anksioznosti“ u biblijsko „otkrovenje“) predstavljaju važnu osobenost proze Flannery O'Connor.

Ključne riječi: Fleneri O'Konor, gotika, Mudra krv, „Hram Svetog Duha“, djeca-protagonisti

\footnotetext{
* $\quad$ vlvujosevic@gmail.com

** Uz određene izmjene, ovaj rad odgovara poglavljima 6.1. i 6.5.2. doktorske disertacije Gotski motivi u prozi Fleneri O'Konor koju sam odbranio maja 2018. godine na Filološkom fakultetu u Beogradu. Ako nije drukčije naznačeno, prevodi su moji.
} 


\section{„Gotska optika“" $\mathrm{i}$ anksioznost pogleda}

Fascinacija ,zazornim“' u središtu je vizuelnog identiteta gotske fikcije. Gotika je, kako ističe Misha Kavka, žanr u čijem središtu nisu toliko narativ, zaplet i likovi, koliko vizuelni ,spektakl“ (Kavka 2002: 209). Sam je gotski „objekat“ prikazan kao nešto „transgresivno“: on je istovremeno izvor „fascinacije i repulzije“ (O’Malley 2006: 211). Poput Aglajonovog sina Leontija iz Platonove Države koji želi da vidi leševe ubijenih i istovremeno se gadi tog prizora (Država 440a), gotski likovi neprekidno ispoljavaju sličnu fascinaciju onim odbojnim i neprijatnim: u gotskom tekstu na djelu je neka vrsta problematične vizuelne opsesije „ružnim“.

Gotski akteri često nemaju mira dok ne utvrde svojim očima objekat užasa. Oni su privučeni spektaklom monstruoznosti. Gotika predstavlja potragu za vizuelnom eksplicitnošću objekta užasa. „Gledanje“ je u središtu gotske reprezentacije. To je žanr koji je opsjednut nedozvoljenim uvidima, nedozvoljenim užicima, zabranom gledanja. Gotska se fikcija tako stalno pokazuje kao anksioznost pogleda. U pitanju je stalna potreba da se vidi, da se utvrdi šta je to što gledamo (up. Kavka 2002: 227). Ovu vrstu tekstova karakteriše (često frustriran) pokušaj da se vidi ono što je pokriveno, da se strgne zastor: da se dođe do ,potpune vidljivosti stvari, ljudi i istina“ (Foucault prema Castricano 1998: 202). Gotika je književnost vela.

U ovom kontekstu dobro je sjetiti se Lynchovog filma The Elephant Man iz 1980. godine. Protagonista ovog filma smještenog u period viktorijanske Engleske je čovjek sa drastičnim facijalnim deformitetom. Film u diskurzivnom smislu predstavlja otkrivanje „deformiteta“. Veo u jednom trenutku spada sa lica: gledamo ,stvar“ koju istovremeno želimo i ne želimo da vidimo. Mi želimo da vidimo prizor za koji znamo da je duboko odbojan. „Čovjek-slon“ zarađuje za život na jedini način koji je njemu moguć: on je atrakcija cirkuske „kuće strave“. Ovakve anomalne lokacije prisutne su i u prozi Flannery O'Connor: cirkuski šator skriva nešto užasno, opsceno, nešto što je samo za „odrasle“, no u njega ipak prodire dijete - dječji pogled. „Gotsko“ se kod O’Connorove javlja u pokušajima da se

1 Sintagma "gothic optics" našla se u naslovu rada Petera Schwengera objavljenom u Gothic Studies (Vol. 7, maj 2005).

2 Ovdje koristimo Kristevin pojam „zazornog“ ('the abject'). Tipičan primjeri te „abjekcije“ su leševi (fascinacija odbačenim tijelom), odsječeni udovi, deformiteti, rane, tjelesne tečnosti, ekskrementi (Kristeva 1982: 3). 
izađe na kraj sa „mračnim“ tajnama odraslih iz nepovlašćene perspektive djeteta.

\section{Intruzija pogleda: problematični užitak gledanja u Mudroj krvi}

U potrazi za gotskim objektom užasa postoji nešto „voajersko“: stalno imamo osjećaj da gledamo nešto što ne bi smjelo da se vidi, što bi trebalo da ostane skriveno. Užitak gledanja, u gotskom tekstu, problematičan je i sporan. To je jedna sličnost koju, možda, gotska fikcija dijeli sa pornografskim žanrom ${ }^{3}$ : u pitanju je jedan oblik eksploatacije. Sam pogled je tu nešto neumjesno, intruzivno, emotivno problematično. Iz svoje privatnosti, gledamo ljudsko biće koje je konstruisano kao nešto „čudovišno“, alijenirano u svojoj brutalnoj ogoljenosti. Pažljivo, (,bezočno“) posmatramo nešto čemu ne bismo smjeli da pridajemo toliku vizuelnu pažnju. Gotski pogled često je dat iz perspektive uljeza. Mjesto tuđe deformacije (neke skrivene somatske istine, ,sramote“) otkriva se našem anatomskom, koncentrisanom pogledu.

Idealno mjesto za ovakve spektakle su tajanstvene prostorije u cirkusima - nekakav peep show koji se javlja kao čest motiv u O'Connorinoj prozi. U romanu Wise Blood (Mudra krv), Hazel Motes će kao dječak proviriti u jednu takvu prostoriju u kojoj odrasli muškarci gledaju nešto što dječak ne može razumjeti, iako može osjetiti da je u pitanju nešto „loše“, nešto što ne bi trebalo da se gleda:

Jednom kada je bio mali, otac ga je odveo na karneval koji se održavao u Melsyju. Bio je tu jedan šator za koga je ulaznica bila nešto skuplja i koji je bio sklonjen u stranu. Sparušeni čovjek sa glasom nalik na zvuk trube reklamirao je sadržaj šatora. Nije govorio šta je unutra. Rekao je samo da je to nešto tako pakleno uzbudljivo (SINsational) da će svaki muškarac koji bude želio to da vidi, morati da plati trideset pet centi. [...] Otac ga je poslao u drugi šator u kojem su dva majmuna plesala, a sam se zaputio onamo. [...] Hazeu su ubrzo dosadili majmuni i krenuo je za ocem, ali nije imao trideset pet centi. (O’Connor 1964: 37)

3 „Gotska književnost, na svim nivoima, suočava se sa rizikom da postane hororpornografija“" (Fiedler 1960: 480). 
Dječak pokušava da sazna šta je u ,zabranjenom šatoru“: „Da li je unutra crnac? [...] Da li nešto rade crncu?"“(O’Connor 1964: 38). U dječjoj svijesti, sadržaj šatora je kodiran kao nešto vezano za nasilje i poniženje: za brutalno otkrivanje neke „ranjivosti“. Unutra je neko ko je izložen nasilju. Sadržaj prostorije dječak identifikuje kao nešto ,gotsko“: gotski je sadržaj nešto „skriveno“, nešto što „,izaziva mučninu, što prelazi granice ukusa i izdržljivosti““ (Fiedler 1960: 115).

U šatoru je nešto što „,izaziva“, traži posredovanje pogleda, te predstavlja vizuelni izazov. Samo odrasli muškarci to mogu da vide: unutra nema žena i djece. To je nešto samo za izdržljive. Sjetimo se kako brat i i sestra, Henry i Judith, kao djeca, skriveni posmatraju krvavu borbu njihovog oca sa „divljim crncima“" u Faulknerovom Absalom, Absalom!. Henry povraća i pada u nesvijest od prizora kojem prisustvuje (up. Faulkner 1990: 21). Skriveno prisustvo djece, njihov pogled na skriveni čin nasilja, postaju važan gotski agens. Gotika je gotovo uvijek užas predstavljen iz perspektive ,nevinog pogleda“: pogleda koji mora da izađe na kraj sa interpretacijom. Objekat uživanja odraslih sada se pokazuje, u dječjoj svijesti, kao nešto „čudno“ što zahtijeva tumačenje, posredovanje. Gotika se nanovo pokazuje kao „epistemička anksioznost“ u kojoj se pitanje „Šta je to što vidim?" neprekidno postavlja.

Gotika se javlja kao oblik nerazumijevanja, kao pokušaj da se izađe na kraj sa onim što vidimo. Sjetimo se samo kako Faulknerov Sutpen postaje za Rosu Coldfield asociran, još od njenog djetinjstva, sa čudovištem (ona često koristi izraze kao što su ogre i ogre-face). Taj Sutpen koga, dok se nije vratio 1866 . godine, ona ,nije vidjela više od sto puta“, postao je „svirepo čudovište njenog djetinjstva“ (Faulkner 1990: 48), a njegova kuća nalikovala joj je na zamak Plavobradog (Faulkner 1990:47). Sutpen postaje čudovište, svirepi Plavobradi, prvo kroz posredovanje dječjeg ,pogleda“ - kroz okulaturu djetinjstva „tog ostarjelog i drevnog odsustva mladosti koje se sastojalo od prisluškivanja iza zatvorenih vrata, poput neke Kasandre, od skrivanja po zamračenim prostorijama ispunjenim onim prezbiterijanskim efluvijumom žalosnog i osvetoljubivog iščekivanja“ (Faulkner 1990: 47). Djetinjstvo je ovdje (kao i u ' A Temple of the Holy Ghost" Flannery O'Connor u kojem djevojčica-protagonistkinja sluša nejasan govor odraslih o „hermafroditizmu“ ili u Mudroj krvi u kojoj dječak Hazel Motes, posmatra, kako ćemo vidjeti, golu ženu u cirkusu) postalo 
mjesto nevine perspektive iz koje se, kao kroz ključaonicu, kroz nedozvoljen pogled prepun nejasne krivice i tabua djetinjstva (ili kroz zatvorena vrata, da bi se čuo razgovor) može vidjeti (ili čuti) nešto od tajni odraslih, neka još uvijek mračna i nejasna istina o stvarnom životu i svijetu, govor ili prizor posredovan kodovima opreznosti, odlomcima prijetećih riječi. Potrebna je ,nevinost“ da bi se govorilo o nečem zastrašujućem. Gotika se uvijek javlja kao semantika nerazumijevanja, kao znakovi i motivi, kao atmosfera koja treba da ispuni prazninu ostavljenu nepotpunim razumijevanjem. Gotski se diskurs javlja tamo gdje postoji neka netransparentnost, zagonetka u pogledu prirode svijeta i ljudi, nešto neodgonetljivo i mračno, one, kako kaže Berlin, „tri četvrtine ledenog brijega“ (Berlin 1999: 109).

Djeca su idealni gotski akteri jer su uvijek isključeni iz ozbiljnih razgovora odraslih, uglavnom ,pošteđeni“ surovih istina života. Do njih, kod kod O'Connorove, dopiru samo odlomci razgovora, po neka opskurna i nejasna, zastrašujuća riječ. Lica smrti, zla, seksualiteta odraslih, preljube, patnje, deformiteta, za djecu se tako na samom početku otkrivaju kao nešto „mucavo“, nedorečeno, samim tim još ominoznije, strašnije od cijele istine. Djetinjstvo je tako prirodni prostor vjere u čudovišta i vještice. Ogre i ogre-face su kodovi u Absalom, Absalom!, maske koje iskrsavaju tamo gdje je, za djevojčicu Rosu, nešto nejasno u pogledu Sutpena, nešto netransparento. Čudovište uvijek nešto skriva: to je izobličena istina „lica“ zastrašujuća maska koja ukazuje na tajnu, jezivu nevidljivost onoga ispod nje. Iako nisu samo djeca gotski akteri, ipak, možemo tvrditi, potrebno je neko „djetinjstvo“ (neka „nevinost“ ili ,naivnost“) sa svojim babarogama i strahovima od čudovišta u ormaru, od bauka ispod kreveta, da bi priča postala nešto gotsko.

U Mudroj krvi čuvar pripušta Hazela Motesa u šator, iako je djeci unutra zabranjen ulaz, u činu koji predstavlja neku vrstu preranog pripuštanja (inicijacije) muške djece u svijet seksualnosti odraslih. Seksualitet u patrijahalnoj ekonomiji O'Connorinog gotskog Juga postaje test izdržljivosti: kao muškarac, iako još uvijek dječak, Haze je pripušten u unutrašnjost šatora kao na neku vrstu preuranjenog testiranja sopstvene muškosti. On treba da ,izdrži“" ono što se unutra nalazi. Kao muškarac, on treba da gleda a ne da žmuri. Seksualnost postaje, ne mjesto užitka već „hrabrosti“: to je nešto sa čim treba da se suočiš a da ne trepneš. Jednom kada uđe unutra 
sve što je mogao da vidi bila su leđa muškaraca. Popeo se na klupu i pogledao iznad njihovih glava. Svi su gledali prema dolje, ka udubljenju u kojem je ležalo nešto bijelo što se pomalo migoljilo u kovčegu oivčenom crnom tkaninom. Na trenutak je pomislio da je u pitanju neka odrana životinja, ali onda je shvatio da je to neka žena. Bila je debela i imala je lice kao bilo koja druga žena osim što je i imala mladež na kuku koji bi se pokretao kad bi se ona smiješila. [...] „Kad bi po jednu vakvu ugradili u svaki sanduk“, njegov otac je dolje, u prvom redu, govorio, ,vala bi bio spreman da ranije odapnem". (O’Connor 1964: 38)

Prvi susret sa ljudskom seksualnošću u dječaku ne izaziva osjećaj uzbuđenja već čuđenja: on vidi ono što ne primijećuje niko od odraslih. Njegov prvi utisak da gola žena u mrtvačkom sanduku (inače, doslovni gotski pulp motiv) liči na odranu životinju ukazuje na brutalnost voajerskog pogleda: voajerski pogled je ono što ide ispod kože, što je, u svojoj želji da „vidi ispod“, brutalno i nasilno. Kao i u pripovijetki „Hram Svetog Duha“ i u ovoj sekvenci Mudre krvi prikazan je susret djeteta sa svijetom seksualnosti kao sa svojevrsnom mračnom enigmom. Dijete otkriva neku tajnu ,života odraslih“ - nešto skriveno što ne uspijeva da razumije do kraja. Govor o seksualnosti uvijek je posredovan kodovima, nejasnim jezikom, „nejasnom krivicom“ koju osjeća Hazel Motes. Govoreći o viktorijanskoj gotici, Biljana Dojčinović navodi utisak Ellen Moers da „doprinos 'književnosti o čudovištima' jeste priča o erotskom životu dece, o dečjoj sobi koja je bila 'jedini heteroseksualni svet koji su viktorijanske književnice - usedelice mogle slobodno da istražuju' (Moers prema Dojčinović 1993: 96). Motiv „sobe“ ovdje je zamijenjen šatorom, tajnom sobom sa posjetiocima skrivenim u mraku: mjesto gdje se nešto što je prethodno povučeno iz javnog prostora nudi kontrolisanom pogledu. „Sakriti nešto“ znači, sada, pozvati da se to vidi: izazivati pogled.

Iskustvo gledanja nikad nije nešto „nevino“. Sjetimo se samo katoličke prakse „čuvanja pogleda“ (tzv. custodia oculorum). Ambivalentnost pogleda neprekidno je prisutna u gotskoj fikciji. Kada se Haze vrati kući, njegova majka zna da je on vidio nešto što nije smio da vidi. Njegova majka, kalvinistkinja, preuzima ulogu religioznog cenzora seksualnosti. Religija se u gotskoj prozi gotovo uvijek javlja kao mračna cenzura seksualnosti. 
Kada se vrati kući, majka zna da je Haze nešto vidio. Njeno znanje uvedeno je kao nešto „,sveznajuće“, sa gotskom ,sugestijom natprirodnog“ (O’Malley 2006: 12). O’Connorova ovdje koristi gotsku konvenciju religiozne regulacije polnosti. Hazeova majka obučena je u dugačku crnu haljinu, poput pripadnice neke menonitske zajednice i u svojim rukama ima prut - znak da je Haze vidio nešto što nije smio da vidi - da je „sagriješio““ pogledom:

Kada se vratio kući, njegova majka je stajala pored kotla u kome se prala roba u dvorištu i gledala je u njega. Uvijek je nosila crninu i njene haljine su bile duže od onih koje su nosile ostale žene. Stajala je tamo, uspravna, zureći pravo u njega. Otišao je iza drveta da se skloni od njenog pogleda, ali je, za nekoliko trenutaka, mogao da osjeti kako ga posmatra kroz stablo. Ponovo je vidio udubljeno mjesto i ponovo onaj kovčeg i [...] ženu u njemu. [...] Stajao je naslonjen na drvo, čekajući. Udaljavala se od kotla i prilazila mu je sa prutom. Rekla je, „Šta si to vidio?“" „Šta si to vidio?" rekla je. „Śta si to vidio?" rekla je koristeći neprekidno isti ton glasa. Udarila ga je prutom po nogama, ali njegova koža kao da je bila od drveta. „Isus je umro da bi te otkupio“, rekla je. „Nisam to tražio“, promrmljao je. (O’Connor 1964: 38-39)

Primijetimo jednu polisemiju pogleda u ovom Hazelovom sjećanju na događaj koji se dogodio kada je imao svega deset godina. Pogled, nešto centralno za gotsku fikciju, gledanje nedozvoljenog, voajersko posmatranje, ,penetrirajuće oko“4 , sada se javlja kroz evociranje biblijske semantike. Adam i Eva poslije kršenja Božje zapovijesti - transgresija je i tu posredovana pogledom: plod koji su pojeli bio je „lijep za oko“ (Post. 3:6) - otkrivaju da su goli: njihove oči se „otvaraju“, sugeriše biblijski tekst, za polnu razliku koje su bili nesvjesni. Pogled postaje mjesto iskušenja, znanja nedozvoljenog, „ogoljavanja“: on posreduje pojavu stida i krivice. Osjećam stid kad sam ulovljen tuđim pogledom. Tuđi pogled omogućava da nagotu vidim kao mjesto srama. $U$ istom biblijskom narativu, javlja se Božje svevideće oko: pogled od koga Adam i Eva pokušavaju da se sakriju. Gledanje posreduje skoro sve događaje u biblijskom narativu Pada i praro-

$4 \quad$ Izraz koji se našao u naslovu studije Maxa Finchera (2007), The Penetrating Eye: Queering Gothic in the Romantic Age (New York: Palgrave Macmillan). 
diteljskog grijeha. Sve je to reizvedeno u ovoj sekvenci kod O'Connorove. Bog zove Adama: „Gdje si?“ (Post. 3: 9) a majka govori Hejzu: „Šta si to vidio?" O’Connorova u ovoj kratkoj sekvenci reizvodi biblijsku sliku praroditeljskog grijeha. Biblijski se hipotekst javlja kod O'Connorove posredovan gotskim idiomom (povezivanjem pogleda, nevinosti i ,zazornog“ objekta). Ključ za gotske scene, za njihovu semantičku „neizvjesnost“”, je u otkrivanju ,svete istorije“ koja se u njima neočekivano ponavlja.

No, slika kojom počinje starozavjetna istorija ljudi, za O'Connorovu je značajna tek kroz okulaturu hrišćanstva. Kao što su oci crkve smatrali da starozavjetne scene, poput sijenke, ukazuju na novozavjetne događaje, pa je tako Hristos novi Adam, a Božja prijetnja Evi da će biti u neprijateljstvu sa zmijom postaje blagoslov, proročanstvo o Mariji kao pobjednici nad đavolom, drvo poznanja dobra i zla postaje drvo krsta, i u Mudroj krvi se, usred evokacije Knjige postanja kao narativa o Padu, javlja i novozavjetna ikonografija. To prisustvo biblijske ikonografije u ovoj sceni primijećuje James Mellard: „Asocirajući drveće i krst, neprekidno stavljajući Hazea usred hrišćanskih aluzija, O'Connorova piše: 'Bio je ravnomjerno naslonjen na drvo, čekajući'“ (Mellard 1995: 53). Haze naslonjen na drvo postaje objekt majčinog pogleda: drvo označava mjesto prikovanosti, ,raspetosti“", nepokretnosti u kojoj smo čvrsto fiksirani pogledom.

Kada u viziji djevojčice-protagonistkinje „Hrama Svetog Duha“ cirkuska „nakaza“, hermafordit, skrajnuti objekat pseudoerotske fascinacije $\mathrm{u}$ jednom drugom šatoru, pred voajerskom publikom zadiže svoju haljinu da bi pokazao zainteresovanima mjesto svoje konačne „sramote“, mjesto koje privlači morbidnu fascinaciju tjelesnim deformitetima, on tu vrstu sopstvene degradacije povezuje sa biblijskim narativom: zadižući haljinu da pokaže mjesto polne konfuzije, sopstveno preoznačavanje pola, predeterminaciju polnim osobenostima i muškarca i žene, hermafrodit govori nešto slično onome što apostol Pavle govori Korinćanima. Hermafrodit, kako ćemo vidjeti, neočekivano evocira apostolovo upozorenje: „Zar ne znate? Hram ste Božji i Duh Božji prebiva u vama. Ako ko upropašćuje hram Božji, upropastiće njega Bog. Jer je hram Božji svet, a to ste vi“ (1.Kor. 3: 16).

Ovo su sve hermeneutički zagonetna mjesta: trenutak koji bi ukazivao na opsceno zadovoljstvo gotske fascinacije nakaznim, polnim, deformisanim, nenormiranim, kroz biblijski diskurs se pokazuje kao mjesto 
„skandala“ hrišćanske vjere (up. 1. Kor. 1: 23). Šatori kao mjesta otkrivanja nepoznatog i skrivenog postaju, kod O'Connorove, mjesta ,inicijacije“ ne u svijet perverzije i sadističkog voajerizma publike koja gleda te spektakle, već u somatsko središte hrišćanstva: u iskupljenje kroz nasilnu smrt i raspeće. ${ }^{5}$

Anthony Di Renzo, koristeći izraz Paule Uruburu, pripovijetke Flannery O'Connor označuje kao „krucifikcije“ ('crucifictions') - literarno tretiranje događaja koji „na zapanjujući način utjelovljuju“ Hristov život, smrt i vaskrsenje u savremenim, sekularnim kontekstima (up. Di Renzo 1993: 42). Nejasna perspektiva dječjeg pogleda traži osmišljavanje prizora: u pitanju je potreba da se opskurna gotska sekvenca uobliči u stabilnu priču. Ključna osobenost O'Connorine proze je upravo ovo „epistemičko skliznuće“" (O’Malley 2006: 88) iz mračne i opskurne tajne u jezik biblijske sakralnosti. Kompromitovane gotske istorije zamijenila je istorija spasenja.

\section{Cirkus nakaza i šator od sastanka: opasnost pogleda u „Hramu Svetoga Duha“}

Protagonistkinja pripovijetke „Hram Svetoga Duha“ je dvanaestogodišnja djevojčica koja živi sa majkom. Njima u dvodnevnu posjetu dolaze njihove četrnaestogodišnje rođake, Joanne i Susan, polaznice katoličke internatske škole. Djevojke-tinejdžerke će boravak „,na slobodi“, izvan striktne atmosfere katoličkog internata, iskoristiti da sa dvojicom lokalnih mladića posjete vašar koji se održava u gradu. Kada se kasno uveče vrate u sobu koju djele sa djevojčicom, misleći da njihova dvanaestogodišnja rođaka spava, Joanne i Susan jezikom nedorečenosti govore o nečemu što su vidjele u jednom od vašarskih šatora. U pitanju je nešto seksualno i anomalno.

Joanne i Susan ne uspijevjaju da jasno kažu što su vidjele na vašaru. Ne uspijevaju da terminološki fiksiraju gotski objekat fascinacije. Jer kad

5 Središnji događaj „svete istorije“ - Kalvarija - postaje mjesto fascinacije pogledom, lokacija nasilja, deformacije, opsjednutosti „,krvavim“ detaljima. Američka teološkinja Fleming Rutledge kaže: ,Važno je, mislim, da se zna da je u drevna rimska vremena metod raspeća bio summum supplicium, ultimativna kazna. [...] Degradacija koja je bila posljedica javnog pokazivanja bila je glavna osobenost ovog metoda [pogubljenja]. Raspeti nesrećnik bio bi prikovan na krst, kao primjer maksimalnog izlaganja, prizivajući na sebe javnu odbojnost i zgražavanje“"(Ben DeHart 2016). 
bi to uradile, nestao bi osjećaj sablasnosti, gotske „vjere u duhove“. One kao da kažu: „ono“. Kao da je u pitanju neka ostenzivna riječ koja ukazuje na pojavu nečega što izmiče kategorijama. One su nešto vidjele, ali to ne uspijevaju da verbalizuju, da tome daju „tijelo“ jezika, izraz. Njihove riječi su kao duhovi: nešto što je u potrazi za svojom supstancom, za istinom o sebi, za svojim licem. Jedna sestra kaže drugoj, misleći da djevojčica, koja s njima dijeli sobu, spava: ,'Dopalo mi se sve, ali znaš-na-šta-mislim (the-you-know-what)', i njeno lice poprimi neobičan izraz kao da govori o nečemu za šta ne može da odluči da li joj se sviđa ili ne“ (O'Connor 1971: 244). Djevojčica koja je budna sluša taj razgovor, ali ne uspijeva da mu dokuči smisao. Nešto je uvijek prećutano.

Govor o tijelu (naročito pred djecom) uvijek je posredovan kodovima opreznosti. Ovaj nejasan način govora sugeriše da je u pitanju nešto što nije za dječje uši, no što istovremeno privlači djevojčicu. To je mjesto gdje jezik više nije dovoljan, gdje je u pomoć potrebno pozvati mimiku tijela (,'znaš-na-šta-mislim' i njeno lice poprimi neobičan izraz"): nejasnoća jezika se prenosi na tijelo (crvenilo obraza nas odaje kada, na primjer, pokušamo da prikrijemo nešto ili da govorimo o osjetljivim temama). Djevojčica je tek sad zainteresovana da sazna o čemu se radi, jer primjećuje da je to nešto o čemu ona ne smije ništa da zna. Gotika je anksioznost spoznaje: potreba da se „vidi“ ono o čemu je teško govoriti. To je uvijek frustrirana želja da se gleda otvorenim očima. Ono na šta misle Susan i Joanne kada kažu ,znaš-na-šta-mislim“ nisu drugo do „duhovi“, aveti govorenja, nešto što „ostaje u zraku“ bez mogućnosti da se premetne u izraz.

Djevojčica čuje kako njene rođake govore o nekoj cirkuskoj nakazi koja je istovremeno i „muško“ i ,žensko“. Ona ne razumije šta to znači. Iz njene nevine perspektive govor o opscenim anatomskim detaljima ostaje trajno zarobljen u kriptičnosti. Postoji neko biće koje u cirkuskom šatoru malobrojnoj publici pokazuje neki svoj skriveni deformitet. Djevojčica u polusnu rekonstruiše tu nejasnu scenu kao neki sveti obred, u kome tajanstveno biće, gotovo pobožno, pokazuje svoje tijelo kongregaciji koja to posmatra u svetoj, misnoj tišini. Hermafrodit u njenoj rekonstrukciji šapatom govori prisutnima o svetosti tijela. On kaže vjerničkoj zajednici da će im ,pokazati nešto“ ali da se ne smiju nasmijati. Kada zadigne svoju plavu haljinu, da pokaže mjesto tjelesne nenormiranosti (nešto što je za djevojčicu još uvijek nejasno), „nakaza“ govori u polumraku, kao neki 
propovjednik sa upečtaljivim južnjačkim akcentom: „Bog mi je ovo učinio i ja ga hvalim!“‘ (O’Connor 1971: 246).

Pravi vašar kurioziteta sa svojom opscenom publikom koja nalazi morbidni užitak u posmatranju tjelesnih deformiteta (,kepeca“, „džinova“, sijamskih blizanaca, „hermafrodita“) sada je, u svijesti djevojčice, postao sveti prostor u kojem propovjednik govori kongregaciji koja pobožno, u tišini, sluša svete riječi: „Duh Sveti je u vama, zar to ne znate? Ako li ko oskrnavi hram Duha Svetoga, Bog će ga zgromiti, a ako se nasmijete i vas će udariti kao mene. Hram Božji je sveta stvar! Amin! Amin!“ (O’Connor 1971: 246). Djevojčica tone u san, dok zamišljena kongregacija prihvata hermaforditovu besjedu i molitveno ponavlja riječi potvrđivanja: „Amin! Amin!“(O’Connor 1971: 246).

Djevojčica sjutradan prisustvuje euharistijskom klanjanju i misi, te se, u najsvetijem trenutku, dok sveštenik podiže hostiju, sjeća „događaja“ sa cirkuskom nakazom od sinoć:

Njen um je počeo da se smiruje, a zatim kao da je bio ispražnjen, ali kada je sveštenik podigao monstrancu sa hostijom koja je unutra u središtu sijala bojom slonovače, pomislila je na šator i na nakazu u njemu. Nakaza je govorila: „Ja ne sporim Njegovu volju. Ovo je način na koji me je On stvorio“. (O’Connor 1971: 247-8)

Di Renzo ne želi da nam promakne išta od skandaloznosti ove pripovijetke. On kaže da je ovo priča o tome kako tijelo hermafrodita preuzima „sakramentalno značenje same euharistije“. I onda dramatično dodaje: „O’Connorova se igra sa blasfemijom“ (Di Renzo 1993: 82). Isti autor skreće pažnju da su u ovom odlomku združeni „monstrum i monstranca“ (Di Renzo 1993: 89). Obje riječi su vezane za „pokazivanje“ (monstrare): za otkrivanje objekta pogledu. Richard Kearny tvrdi da monstrare istovremeno znači ,pokazati““ i „upozoriti“ (Kearney 2003: 5). Hermafrodit u rekonstrukciji djevojčice pokazuje ali i upozorava. U euharistijskom činu vjerničkoj se zajednici pokazuje Hristovo tijelo koje je učinjeno nemoćnim, kenotičnim, ono je predato vlasti i spektaklu pogleda u liturgiji, ali tu „otkrivenost“ nemoći istovremeno prati „upozorenje“ o „sudu i osudi“ koji će sustići one koji ga se nedostojno i bez vjere dotiču.

Ova dvoznačnost skrivenog objekta fascinacije koji istovremeno može funkcionisati kao nešto gotsko i sakralno, kod O'Connorove je dalje 
istaknuta kroz polisemiju motiva šatora. Šator je mjesto zabranjenog, erotskog i nerazumljivog, ali i svetog, povlašćenog. U oba slučaja to je mjesto vezano za „krizu reprezentacije“. Nikada kod O'Connorove nije sasvim jasno šta tačno vidimo jednom kada se podigne zavjesa na opskurnoj karnevalskoj pozornici.

„Šator“ u Starom zavjetu opisuje „mjesto sastanka“ u kojem boravi sam Bog nad vojskama u Silomu. Starozavjetni šator je i mjesto „svetog užasa“" jer on u sebi skriva najsvetiji objekat - Kovčeg saveza koji uništava fizičku supstancu onih koji ga se nedostojno dotaknu: poput Uza koji kada, kod gumna Nahonova, nedostojno dodirne Kovčeg saveza biva pokošen na mjestu (2 Sam. 6:7). Čak i samo gledanje u Kovčeg saveza može biti fatalno. U Vet-Semešu, u starozavjetnom narativu Prve knjige Samuilove, gine na mjestu pedeset hiljada i sedamdeset ljudi koji su nepobožno i drsko posmatrali Kovčeg saveza (1 Sam 6: 19). Ova zastrašujuća mogućnost nepobožnog pogleda i njegove opasnosti doslovno je reizvedena u „Hramu Svetog Duha“. Očigledno evocirajući događaj podsmijeha Mihale, žene izrailjskog cara Davida, koja se, vidjevši sa prozora svog muža kako u zanosu igra i pjeva pred Kovčegom saveza, nasmijala a potom bila kažnjena jalovošću (2 Sam. 6:16-23), cirkuski hermafrodit upozorava: „Bog me je stvorio ovakvim i ako se nasmijete i vas će udariti na isti način“(O’Connor 1971:245).

\section{Gotska hermeneutika „dječje sobe“: motiv intimne čudovišnosti}

U „Hramu Svetog Duha“ djevojčica-protagonistkinja susreće se sa tri tijela: svojim sopstvenim, tijelom cirkuskog hermafrodita (,čudovišnim tijelom") i tijelom Hrista u hlebu Euharistije (,,svetim tijelom“). Sopstveno tijelo ovdje je ono „neoznačeno“, a samim tim i najproblematičnije. Tijelo hermafrodita („čudovište“/ „nakaza“) posreduje između „sopstvenog tijela“ i tajne euharistije (,svetog tijela“). „Sopstveno tijelo“ tako se našlo između onog „,najnižeg“ (,zazornog“, „nakaznog“) i onog „najvišeg“ (,svetog“, ,sublimnog“).

Djevojčica koja se nalazi u osjetljivom uzrastu adolescencije ne prihvata sebe, svoje tijelo, svoju majku; ona iznutra pati i svađa se sa svima. Ona je tomboy figura južnjačke gotike kakvu smo sreli kod Harper Lee i Carson McCullers; djevojčica koja je prisiljena da se ponaša kao dječak, da bi sakrila osjećajnost, bolnu slomljenost koju dijete prvi put susreće kroz medijum tjelesnog sazrijevanja. 
Pripovijetka počinje dolaskom djevojki Joanne i Susan. One neprekidno koriste priliku da prođu pored ogledala u holu kuće. Ogledalo, motiv prominentan u ovoj pripovijetki, je, na specifičan način, medijum konflikta adolescencije, stvaranja slike o sebi, mjesto gdje se dolazi u dodir sa svojim likom kao tuđim. Ogledalo omogućava da sebe vidimo kao nekog drugog, da pokušamo da sebe vidimo onako kako nas drugi vide. Adolescencija je, u ovoj O'Connorinoj pripovijetki, prikazana kao narcistički spektakl tuđeg pogleda. No, tijelo adolescencije postaje, istovremeno, i gotski, ,zazorni“ objekat: ženstvenost se otkriva, po prvi put, kroz ,zazorne“ promjene, kao nejasni nagovještaj „čudovišnosti“ i tajni „odraslog“ života. Julija Kristeva kao primjer ,Zzazornog“ ('the abject') često pominje menstrualnu krv (Kristeva 1982: 71). Isticanje krvi koje je obično vezano za smrt ili ozbiljnu povredu, sada postaje vezano za neku nejasnu istinu sopstvenog tijela, za promjenu djevojčice u ženu. Krv je kod O'Connorove mjesto „mudrosti““ (sjetimo se samo naslova romana Mudra krv). Djevojčica ne komunicira sa majkom o ovim temama: ona je prinuđena da somatske zagonetke riješava sama za sebe.

Susret sa sopstvenom tjelesnošću ostaje ona neizgovorena privatna, svakodnevna trauma „dječje sobe“ koju Ellen Moers smatra važnom scenografijom gotske „književnosti o čudovištima““ (prema Dojčinović 1993: 96). Djevojčica ima dvanaest godina i mi neprekidno osjećamo da se u njoj odigrava intimna drama koja nikada ne biva verbalizovana, koja se naslućuje tek kroz pokrete, izraze, nerazumijevanja. Ljudska tjelesnost postaje nešto zagonetno, gotski spektakl ,pokazivanja i skrivanja“. Motiv „,̌udovišta“" iz cirkusa tako se javlja kao slika koja treba da nam protumači sopstveno tijelo.

Čudovišnost je u „Hramu Svetog Duha“ smještena u samo središte somatskog razumijevanja. Djevojčica ono ,genitalno“/,reproduktivno“"

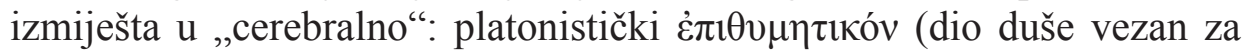

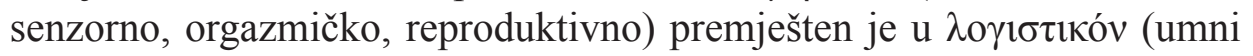
dio duše, jedino mjesto gdje je moguće da se nešto javi kao zagonetka, kao problem, opsesija). Ona kaže da je jednom vidjela ,zeca kako dobija zečeve“" (O’Connor 1971: 245). Tu priču izmišlja da bi natjerala svoje rođake da joj kažu šta su vidjele u cirkusu, jer ono što su one vidjele nije „,za dječje uši““. Ako joj kažu šta su vidjele, ona će im opisati kako izgleda kada zec dobije male zečeve. „Ona zapravo nikad nije vidjela kako zec dobija male 
zečeve ali je na to zaboravila čim su one počele da joj pričaju šta su vidjele u šatoru“ (O’Connor 1971: 245) Djevojčica na kraju, kada Joanne i Susan kažu da su vidjele biće koje je „muškarac i žena“ izmišlja kako je vidjela da zec iz usta izbacuje svoje mlade: ,šestoro njih“ (O'Connor 1971: 246). Djevojčica još uvijek ne poznaje reproduktivnu anatomiju: „Misliš, imalo je dvije glave?"(O'Connor 1971: 245). Gotika je diskurs u kome je najlakše od tijela napraviti cerebralni problem, zagonetku.

„Spektralizacija“ je temeljni postupak gotike: tijelo mora nestati, izgubiti se u svojoj fizičkoj „zazornosti“ i biti zamijenjeno duhom, ukazanjem, mentalnom zagonetkom. „Ponekad se, u tekstualnom smislu, pokazuje da duhovi, ili prije - njihove tekstualne poruke, mogu biti shvaćene. Ali češće, duhovi ostaju oblik neshvatljivog“ (Punter 1998: 4). Duh je entitet koji je oličenje zagonetke. „Spektralizacija“ gotike postaje znak bjekstva od gnusne prirode tijela, od tajne skrivene u ,zazornoj“ tjelesnosti. Gotski diskurs kao da u sebi ima nečeg ,gnostičkog“, nekog zazora od materijalnosti. Gotika je doslovna ,priča o duhovima“.

Bježeći od sopstvenog tijela (koje u procesu ,transformacije“), djevojčica-protagonistkinja nalikuje na gotski subjekat, lik koji se, pred užasom tjelesnosti, pretvara u um, te bježi iz ,genitalnog“ u ,cerebralno“, iz tijela u tekst, „,iz iskustva u jezik“ (Bigsby 2007: 15). Gotski idiom tajnovitosti predstavlja strategiju povlačenja pred prirodom tjela, pred tjelesnim - no kod O'Connorove stvar ne završava duhovima gotike, već povratkom tijela, njegovim „vaskrsenjem“ ${ }^{u}$ sakralnoj i biblijskoj dimenziji. Susret sa sakramentalnom hostijom, vratiće djevojčicu nazad - u sopstveno tijelo. Ono od čega je „bježala“ kao od neprijatnog i ružnog, sada se otkriva kao mjesto „svetosti““, prihvatanja sopstvenog ,čudovišnog“ tijela kao „hrama Svetog Duha“. Užas tjelesnosti postaje događaj svetog. Euharistija (nenormirano, „obrisano“, bijelo, čisto, sveto tijelo) je slika koju koristi da pronađe mir u sopstvenoj tjelesnosti.

\section{„Od devijantnog ka čudesnom": ,srednjovjekovna“ perspektiva dječjeg pogleda}

Govoreći o Lynchovom The Elephant Man, Corinna Wagner ističe kako je naš prvi susret sa Josephom Merrickom, obilježen iskustvom „neugodnosti, užasa koji izaziva sam pogled na tijela koja ne smatramo "normalnim““ (Wagner 2015). Merrick postaje neka vrsta „degradirane, per- 
vertirane verzije ljudskog bića“" (Wagner 2015) koja se izlaže ljubopitivim pogledima cirkuske publike. Pogled publike je ono što Josepha Merricka konstituiše kao čudovište. Naš pogled na deformisano tijelo izoluje „razliku“ u odnosu na tjelesni standard: „Naše visceralno gađenje prema 'zazornim' tijelima usmjerava pažnju na način na koji smo, u istorijskom smislu, podijelili svijet na kategorije normalnog i abnormalnog" (Wagner 2015). Wagnerova navodi uvid Paula Youngquista da je medicinska nauka „,izgradila 'pravo/ispravno tijelo', [a samim tim] i ona koja 'padaju izvan' ove kategorije“" (prema Wagner 2015). Monstruoznost, ključni motiv gotike, razotkriva se kao ultimativni proizvod modernosti. Nenormirana tijela (,cirkuska čudovišta“) „,nas nužno podsjećaju koliko je fragilan naš uređeni svijet“ (Wagner 2015). Oni ,problematizuju naše kategorije, kao i distinkcije koje nam daju osjećaj udobnosti i sigurnosti“" (Wagner 2015).

No, sama Wagnerova je svjesna promjene u percepciji ,čudovišnosti“ koja se desila u epohi modernosti:

„Čudovišta“" su prije predstavljala projavljivanja čudesnog, no u vremenu prosvećenosti, ona postaju figure devijantnosti i disfunkcionalnosti. Ovaj pravac istorijske promjene u načinu na koji vidimo anomalno tijelo, kako je to izrekla Rosemarie GarlandThomson, ,može jednostavno biti okarakterisan kao kretanje od narativa čudesnog ka narativu devijantnog“. „Kako je u zapadnoj kulturi modernost uzimala maha“, argumentuje ona, „ono što je jednom bilo shvatano kao otkrovenje sada se traži kao zabava; što je izazivalo strahopoštovanje, sada izaziva užas (horror). Ono što se smatralo proročanskim prelazi u mjesto progresa. Ukratko, čudesno postaje greška“. Tako dobijamo viktorijanske cirkuse nakaza. (Wagner 2015)

Ovaj put od „,̌udesnog“ do „devijantnog“ kod O’Connorove je pređen unazad. Mi počinjemo sa slikom devijantnog, a završavamo slikom sakralnog. ${ }^{6}$ Tjelesna disfiguracija postaje znak Božjeg djelovanja. Kada se

$6 \quad$ Na sličan način i motivi tjelesnih deformiteta se često javljaju u hagiografskim tekstovima. Tjelesne povrede i deformiteti predmet su naročitog strahopoštovanja. Rane i tjelesne promjene su u centru pažnje, u fokusu pogleda, ali ne ljupopitljive publike koja u tome vidi oblik vašarske zabave ili užasa (a gotika je često percipirana kao popularni žanr koji se bavi prizorima užasa) već kongregacije koja u tjelesnim abnormalnostima vidi 
u „Hramu Svetog Duha“ dvije djevojke vrate sa vašara i kažu, kroz kikotanje, da su tamo vidjele dvopolnu nakazu, dvanaestogodišnja djevojčica protagonistkinja je zbunjena i dok leži u krevetu pokušava da zamisli ono što su djevojke vidjele. U tome je već nešto „monstruozno“: hermafroditi su, kako obrazlaže Judith Butler, ,granični ljudi“, oznake za situacije u kojima sama ljudskost postaje nešto upitno (Butler 1993: 8). U svijesti djevojčice cirkuska šatra sa ljubopitivom voajerskom publikom koja je došla da svjedoči gotskom spektaklu nakaznosti i devijantnosti postupno se pretvara u religioznu kongregaciju koja prisustvuje svetom obredu. Šator u kome se predstavlja nakaza, sada postaje crkva u kojoj se pokazuje portentum ili ostentum: strašna misterija tjelesnosti. Publika željna horora, zabave koju nudi gotski prizor, sada se preobražava u crkvenu pastvu a cirkuska nakaza postaje sveštenik. Užas ljubopitljivosti, opscene opaske (poput one koju u jednom sličnom šatoru izgovara otac Hazela Motesa) smjenjuje sveta tišina liturgije: $u$ fokusu je i dalje abnormalno tijelo, ali sada kao medijum Božjeg prisustva.

Kod O’Connorove, spektakl „devijantnog“ postaje prizor ,čudesnog“ tek kroz pogled djeteta koje je upravo onaj ,agens“ koji je oslobođen dugotrajnog djelovanja kulture (značenjske mreže koja omogućava da se abnormalno tijelo pojavi kao nešto „,̌udovišno“), ideoloških kategorija modernosti, (pseudo)scijetnističkog diskursa o patološkim varijetetima. Djeca, na neki način, kod O'Connrove stoje izvan kulturnog mainstreama ljudskog svijeta, te su samim tim njihove vizije stvarnosti otvorenije za „čudesno“. Djeca su pod slabijim uticajem dominantne kulture. Postoji nešto predmoderno, skoro srednjovjekovno u „nevinosti“ djece u prozi Flannery O'Connor. U vizijama djece u njenim pripovijetkama „cirkus

neku specifičnu imitatio Christi. Tijelo sveca sa ranama i stigmatama postaje spektakl (spectaculum, nešto dostupno javnom pogledu), ali ne gotski spektakl devijantnog, već čudesnog. U kontekstu poštovanja svetih tijela, rane neprekidno dolaze u prvi plan. Na tijelu Franje Asiškog pojavljuju se čudne rane, koža na njegovim stopalima i rukama se deformiše tako da izgleda kao da iz njegovog tijela izlaze čudni nedefinisani objekti. U pitanju je pojava, ostentum, koja podsjeća na eksere: „Čudo stigmata na stopalima i rukama predstavljalo je čudesnu promjenu tjelesnog oblika. Koža bi postala tamnija i uzdigla bi se formirajući trodimenzionalni oblik eksera koji bi, kada bi se dotakli, pružali senzaciju drugačiju nego što je to slučaj kada se dodirne normalna koža. Oni su bili koža i nisu bili koža, bili su ekseri i nisu bili ekseri. Čudo je ovdje uspostavljeno kroz abnormalnost Franjinog fizičkog tijela“" (Warr 2016: 51). 
nakaza“" (problematičnu zabavu odraslih) zamijenio je spektakl čudesnog. Gotski deformitet rascvjetao se u stigmate.

\section{LITERATURA}

Berlin, I. (1999). The Roots of Romanticism (ur. Henry Hardy). Princeton, New Jersey: Princeton University Press.

[Ben DeHart]. (2016, Oct. 10). Fleming Rutledge on 'The Crucifixion' [video zapis]. Preuzeto sa: https://www.youtube.com/watch?v=Hg50KEoiDsU. [Приступљено: 22. 12. 2017.]

Bigsby, C. (2008). 'Tennessee Williams'. The Cambridge History of American Literature, Vol. 7; Prose Writing (1940 - 1990). Ur. Sacvan Bercovitch. New York: Cambridge University Press.

Butler, J. (1993). Bodies That Matter. New York \& London: Routledge.

Castricano, J. (1998). “'If Building Is a Sentence, So Is a Body': Kathy Acker and the Postcolonial Gothic". American Gothic: New Interventions in National Narrative (ur. Martin, R. K. \& Savoy, E.). Iowa City: Iowa University Press.

Di Renzo, A. (1993). American Gargoyles: Flannery O'Connor and the Medieval Grotesque. Southern Illinois University.

Dojčinović, B. (1993). Ginokritika. Beograd: Književno društvo „Sveti Sava“.

Faulkner, W. (1990). Absalom, Absalom! (The corrected text). New York: Vintage International, Vintage Books.

Fiedler, L. (1960). Love and Death in the American Novel. New York: Criterion Books.

Kavka, M. (2002). 'The Gothic on screen'. The Cambridge Companion to Gothic Fiction (ur. J. H. Hogle). Cambridge: Cambridge University Press.

Kearney, R. (2003). Strangers, Gods and Monsters (Interpreting Otherness). London, New York: Routledge.

Kristeva, J. (1982). Powers of Horror: An Essay on Abjection (prev. Leon S. Roudies). New York: Columbia University Press.

Mellard, J. (1995). 'Framed in the Gaze: Haze, Wise Blood, and Lacanian Reading'. New Essays on Wise Blood (ur. Michael Kreyling). Cambridge: Cambridge University Press.

O'Connor, F. (1971). 'A Temple of the Holy Ghost'. The Complete Stories. New York : Farrar, Straus and Giroux. 
O'Connor, F. (1964). 'Wise Blood'. 3 by Flannery O'Connor (Wise Blood, A Good Man is Hard to Find, The Violent Bear It Away). New York: A Signet Book.

O’Malley, P. (2006). Catholicism, Sexual Deviance, and Victorian Gothic Culture. New York: Cambridge University Press.

Punter, D. (1998). Gothic Pathologies: The Text, the Body, and the Law. London: Palgrave MacMillan.

Wagner, C. (2015). "The Elephant Man: Victorian Monstrosities". Screen Talks (Great films, Great Debates - University of Exeter at Exeter Picture House) [Blog Post]. Preuzeto sa: https://blogs.exeter.ac.uk/screentalks/ blog/2015/01/22/the-elephant-man-victorian-monstrosities-celluloid-gothic-intro-by-dr-corinna-wagner-mon-26th-jan/. [Приступљено: 22. 12. 2017.]

Warr, C. (2016). 'Changing Stigmata'. Wounds in the Middle Ages (ur. Anne Kirkham, Cordelia Warr). London \& New York: Routledge, Taylor \& Francis Group.

\section{Vladimir M. Vujošević}

\section{INNOCENCE OF CHILDREN AND SECRET LIVES OF ADULTS IN FLANNERY O'CONNOR'S PROSE}

\section{Summary}

The problem of "seeing" is at the center of Gothic representation. The categories of what was termed "Gothic optics" (motifs of gaze, optical delusions, blindness, light and darkness, evil eyes, etc.) constitute a prominent feature of Gothic fiction. These texts, as various researchers have pointed out, are characterized by (often frustrated) attempts to see (to grasp, to understand) what is hidden and concealed. Gothic fiction often thematizes series of uncanny events from a perspective of an "innocent gaze" (an innocent or naive heroine is a common trope of the genre) which struggles with interpretation. It is not unusual, therefore, that characters of children are commonly found in Gothic literature. Childhood is the natural space of faith in monsters. In Gothic literature, childhood stands for an innocent perspective from which, as if through a keyhole, by an unauthorized gaze, a child can see (or overhear) some secret of the adults, some arcane truth about the life and the world, which always remains, for the child, fragmented and, therefore, frightening. Some kind of "innocence" is always necessary for a story 
to become fearsome. Gothic fabulation of events occurs when some non-transparency is at work, some riddle concerning nature and the world which renders them shattered and dark. Gothic text thematizes "the shadow" of knowing, "the blind spot" into which a part of the story inevitably enters. Something is rendered macabre because it evades thorough understanding. In O'Connor's Wise Blood and in "'A Temple of the Holy Ghost", the child-protagonist reveals some secret feature of the life of adults but ultimately fails to understand it to the full. The child's gaze gothicizes the enigma of adult life into a dark and ghastly story. In O'Connor's prose, carnival tents hide something horrible and obscene, something that is only for "'grown-ups", but is nevertheless captured by a child's gaze. Gothic fabulation emerges in O'Connor with the attempts to figure out the secrets of adults from the unprivileged epistemic position of a child. However, in her prose Gothic perspective is only a transitional phase of the main narrative. The fragmentary Gothic narrative ends up in outright sacral representation. The Gothic gap is filled with sacred imagery in order to render the story whole. The focal feature of O'Connor's prose is precisely this change from the unstable Gothic perspective to more fixed imagery of biblical sacredness. In her work, the tents are locations of the carnival and anomalous, but, at the same time, they are the topoi of sacred, and, thus, they expose the biblical 'hypotext" of O'Connor's prose. In a sense, children are placed outside the cultural mainstream of the adult world, and by virtue of this, their visions of reality are more open to the "wondrous." It is through the visions of children in her stories that the Gothic "freak shows" (problematic entertainment of adults) are, at the final point, replaced by the spectacle of the "sacred".

Key words: Flannery O'Connor, Gothic, Wise Blood, 'A Temple of the Holy Ghost", child-protagonist 